\title{
INCORPORARSE A JESUCRISTO: PRÁCTICAS SACRAMENTALES Y PENITENCIALES ENTRE LOS DOMINICOS CASTELLANOS EN EL SIGLO XVI
}

\author{
POR \\ GUILLERMO NIEVA OCAMPO \\ Universidad Nacional del Sur, Argentina
}

\begin{abstract}
RESUMEN
El movimiento observante entre los dominicos de Castilla desarrolló su virtualidad a partir de la última década del siglo XV. Bajo el impulso del retorno a los orígenes y en el contexto de una sociedad al mismo tiempo en expansión y temerosa del pecado, las comunidades dominicas castellanas desarrollaron un proceso de autoconciencia y categorización que dio como resultado la configuración de un modelo de vida regular en el que la frecuentación de los sacramentos de la Penitencia y de la Eucaristía, así como ciertas prácticas corporales inmoladoras, adquirieron la categoría de rasgos distintivos de los frailes reformados.
\end{abstract}

PALABRAS ClAVE: Castilla, dominicos, reforma, sacramentos, observancias.

\section{ABSTRACT}

The observant movement among Dominicans of Castile developed its potentiality from the last decade of $15^{\text {th }}$ Century. Urged by the wish to return to their origins and within the framework of a society which, on the one hand, was under a process of expansion, and on the other, was fearful of sin, the Dominican communities of Castile brought about a process of self-consciousness and categorization which led to shape a regular life style in which the frequent practice of both the Penance and the Eucharistic sacraments, as well as of some physical practices of immolation acquired the category of distinctive features of the reformed friars.

KEY WORDS: Castile, Dominican, reform, sacraments, observances. 
La reforma de los regulares a lo largo de los siglos XV y XVI fue ante todo un tiempo de ruptura en la historia de las comunidades religiosas durante el cual se enfrentaron, a veces violentamente, observantes y conventuales. Por ende, la actividad reformista fue un estado, pero también un momento generador de conflictos y revelador de tensiones.

En el concilio de Vienne de 1311, los padres conciliares distinguieron la reformatio in membris y la reformatio in capite ${ }^{1}$. Sin embargo, la prioridad no estuvo siempre dirigida a los prelados, como ha observado José García Oro. En las décadas finales del siglo XV ya hacía tiempo que se había decidido que la reforma se aplicara a los miembros de las comunidades. Es por ello que, sobre todo a partir de 1470, la reforma in membris suscitó frecuentemente más interés $^{2}$. Entre otros testimonios, las ordenaciones de los Capítulos Generales de la Orden de Predicadores ilustran esa evolución ${ }^{3}$. En la primera mitad del siglo $\mathrm{XV}$, sus disposiciones se ocupan casi exclusivamente de los prelados, tenidos por responsables de los abusos ${ }^{4}$. Sin embargo, a partir de mediados de la centuria, los padres capitulares comienzan a fustigar directamente a los frailes.

Asimismo, desde su nacimiento, hacia 1471, la Congregación de la Observancia castellana se interesa, ante todo, por corregir a los frailes de los conventos dominicos. La reforma in membris se había convertido en un hecho prioritario entre los dominicos a finales del siglo XV. En el Capítulo de Salamanca de 1489 - el primero de la Congregación de la reforma castellana del que se conservan sus Actas - se expuso la doctrina programática de la reforma dominica en términos disciplinarios y al mismo tiempo se dispuso la reorganización general de todas las comunidades, comenzando por el convento de San Esteban de Salamanca, donde se desarrollaron las sesiones de esta asamblea ${ }^{5}$. Se trató de

1 Esta famosa formulación no fue olvidada al alba del siglo XVI. Por su parte, el concilio de Basilea, en 1348, se había preocupado ante todo por la reforma in capite, considerando que si la cabeza estaba sana, el resto del cuerpo eclesial recobraría su vigor. Por otro lado, al desacreditar y debilitar la jerarquía de la Iglesia, el Gran Cisma paradójicamente reforzó la idea que la reforma debía hacerse principalmente en lo alto: la reforma in capite estaba de moda. Véase F. RAPP, L'Eglise et la vie religieuse en Occident à la fin du Moyen Âge, París, 1971, p. 83; P. CHAunu, Le temps des réformes, París, 1975, pp. 215-287.

2 Ante la evidencia pareciera que la política eclesiástica de los Reyes Católicos se dirigía en ese sentido, más a asegurar la reforma de la Iglesia de sus reinos que a pretender la reforma del Papado. Cfr. M. A. OCHOA BRUn, Historia de la diplomacia española, 1990, IV, pp. 70 y ss.

3 Acta Capitulorum Generalium Ordinis Praedicatorum, MOPH, Vol. VIII, 1909, pp. 133-147, 320-329.

${ }^{4}$ En este mismo sentido se pueden considerar los procesos entre los dominicos de España que llevó adelante Lope de Barrientos contra el Provincial de España Esteban de Soutelo en 1453 y la deposición en 1454 del prior de San Esteban de Salamanca gestionada por el obispo Vivero. Cfr V. BELTRÁN DE HEREDIA, «Los comienzos de la reforma dominicana en Castilla», Miscelánea Beltrán de Heredia, I, pp. 409-413.

${ }^{5}$ Expediente que se repetiría en cada una de las crisis que sufrió la provincia. Por ejemplo en

Hispania Sacra, Estudios de Edad Moderna, 58

117, enero-junio 2006, 39-67, ISSN: 0018-215-X 
una reunión que por su obra legislativa señala un hito relevante y si se quiere inaugural en el proceso de identidad y de autoconciencia de la reforma religiosa entre los dominicos ${ }^{6}$.

En términos generales, la normativa emanada de las asambleas capitulares de la Congregación y, tras su disolución en 1505, de la Provincia, puso en marcha la creación de un modelo de vida regular mucho más acorde con las exigencias funcionales de la sociedad castellana de la época, que con el pretendido modelo original de la Orden de Predicadores ${ }^{7}$. A lo largo del siglo XVI, la elaboración y puesta a punto de dicho modelo se manifestó sobre todo con la aceptación, la ampliación, el rechazo o la matización de las normas promulgadas por las asambleas capitulares, a través de la producción literaria e intelectual de los frailes de la Orden. En efecto, los escritos emanados de los claustros dominicos, en general de obras de teología moral, espiritual y dogmática dedicadas a la lectura de los mismos religiosos, remataría y completaría el proceso creativo iniciado por la generación de frailes legisladores de 1490.

En ese cambio epocal, eminentemente conservador, que caracterizó la vida de los religiosos castellanos a lo largo del siglo XVI, el ejercicio de las prácticas sacramentales y penitenciales en los conventos de la Orden de Santo Domingo, tuvo una significación enorme.

\section{LA PRAXIS SACRAMENTAL}

Los sacramentos eran el signo visible de la pertenencia a la Iglesia y los instrumentos adecuados para la propia santificación, así como el lugar de comunicación del divino y con lo divino. Dan testimonio de la fe e infunden la gracia. Para los religiosos de la observancia, los sacramentos restablecen al fraile en vista de su elevación, son el medio y el signo de su perfección y de su fusión con Dios ${ }^{8}$.

1508, a raíz de la actuación del grupo de Piedrahita los capítulos de ese año y del año siguiente promovieron una redistribución de los miembros de todas las comunidades, algo similar sucedería en 15211522 con posterioridad a la guerra de las Comunidades.

${ }^{6}$ Dos capítulos habrían tenido lugar con anterioridad. De ellos no se conservan sus Actas, pero en el de Salamanca se dispondrá la observancia de la normativa aprobada allí.

${ }^{7}$ Como en el caso general de muchas normas institucionales, las ordenaciones de la congregación pretendieron regular sobre todo conductas observables y en menor medida ideas y sentimientos, valga en este sentido la minuciosa regulación que experimentó la liturgia comunitaria y la casi inexistente ordenación que sufrió, al menos en este período, la oración individual. Una codificación exhaustiva del comportamiento hubiera constreñido más allá de lo deseable la conducta de los religiosos. Fueron reguladas, por lo tanto, aquellas conductas importantes o significativas para las comunidades, sobre todo las que se referían a la supervivencia, funcionamiento adecuado y productividad, así como al bienestar de los miembros.

8 Así lo había entendido Catalina de Siena, considerada la fundadora del movimiento reformista 
Antes de la profesión, el fraile había ya recibido un buen número de sacramentos, seguramente el bautismo, la comunión, la confirmación y, a veces, las órdenes menores. En consecuencia es de cara a la comunión eucarística, al sacramento del orden y de la confesión que los regulares se singularizan, convirtiéndose en grandes consumidores de sacramentos.

\section{LA FRECUENTE CONFESIÓN SACRAMENTAL}

La entrada en el claustro era vivida como una penitencia. En las vidas de santos escritas entre el siglo $\mathrm{V}$ y el siglo $\mathrm{X}$, la vida monástica es presentada como la penitencia por excelencia ${ }^{9}$. Sin embargo, la profesión no extinguía el arrepentimiento y la culpabilidad que oprimían al monje, perpetuamente pecador. La perseverancia en la penitencia se manifiesta a través de una frecuentación asidua de la confesión.

En el interior de un convento dos confesiones eran posibles: una sacramental, era privada e individual, la otra, el capítulo de las culpas, ya sea colectiva como individual, era siempre pública, reservada a la confesión de las faltas veniales. De estos dos procedimientos penitenciales el primero fue muy fomentado por los reformadores castellanos.

En el corazón del dispositivo de la reconciliación se encontraba el sacerdote, abogado y médico del alma ${ }^{10}$. Su intervención esta justificada por su conocimiento. Efectivamente, las luces del predicador y del confesor eran consideradas necesarias para identificar el pecado. Esta dimensión pedagógica de la confesión, schola confessionis, explica el cuidado puesto por los reformadores a la hora de seleccionar los confesores. Debía poseer la ciencia necesaria para administrar el sacramento así como una conducta impecable. La confesión, a su vez, debía ser libre, integral, acusatoria, frecuente y sincera. En general las disposiciones insisten menos sobre el poder de absolución del sacerdote que sobre la función pastoral ${ }^{11}$. Miden el grado de contrición, la extensión, la naturaleza y

\footnotetext{
entre los dominicos. Traducida al castellano por fray Antonio de la Peña en 1510, la santa senese sostenía en sus escritos no sólo la importancia salvífica de los sacramentos sino su capacidad divinizante. Cfr. G. CAVAllini, S. Domenico e i suoi frati nella spiritualità di Santa Caterina da Siena, Roma, 1993, pp. 130-138.

9 Groupe de La Bussière, Practiques de la confesión, París, 1983, p. 77.

${ }^{10}$ Una visión general desde el siglo XII en J. DelumeaU, La confesión y el perdón, Madrid, 1990.

11 Para los dominicos los oficios de confesor y predicador revestían indistintamente un carácter eminentemente pastoral. En este sentido, la reforma castellana no hacía otra cosa que hacerse eco de las disposiciones de los Capítulos Generales que a lo largo del siglo XV habían legislado al respecto. El Capítulo reformista de Colmar, de 1434, mandaba a los predicadores y confesores, «Cum per instituta nostra ad predicandum verbum Dei et confessionum audientiam nullus assumi debeat, nisi sit sciencia, idoneitate et moribus approbatus, statuimus observandum perpetua firmitate, nullum fratrem
} 
la intención del pecado, para poder indicar mejor la reparación, destinada a perfeccionar la penitencia.

A su vez el penitente tenía que realizar una confesión sincera de sus pecados. El fraile no debía «tener vergüenza de confesar sus pecados así secretamente, cuando es menester, como públicamente, que de gran soberbia viene negar el pecado cuando lo ha de confesar». Hay algunos que echando la culpa al diablo, a los compañeros o a las ocasiones niegan sus propios pecados «de manera que nunca de corazón dicen el pecado que hicieron, sino siempre lo envuelven con algunos andrajos, o para que no parezca pecado, o no tan grande». El modelo a seguir por todo religioso, según los reformadores, era el del hijo pródigo (Luc. 15, 21), que se humilló y fue perdonado por su padre ${ }^{12}$. En esto se jugaba su progresión o su regresión en el camino de la salvación, íntimamente vinculada con la conquista de la humildad.

En la Congregación de la reforma española la confesión sacramental era en general semanal, aunque también los religiosos estaban invitados a confesarse en la vigilia de ciertas fiestas y durante una enfermedad. Su regulación era precisa y minuciosa ${ }^{13}$. La elección de confesor era un asunto importante entre es-

de cetero ad predicandum et secularium confessiones audiendum posse assumi, nisi prius per examinatores, in provincialibus capitulis a provinciali et diffinitoribus, vel extra capitulum a magistro reverendissimo et provincialibus deputandis, diligenter examinatus fuerit et sufficiens inventus iudicio predictorum; super his enim eorum conscientias districtius oneramus, omnes et singulos insufficientes ad praedicacionis officium et confessionum audientiam quavis auctoritate promotos simpliciter privando et ab ipso officio absolvendo; insufficientes autem dicimus, quos magister et provincialis, vel quibus commiserint, inhabiles iudicabunt de consilio discretorum, in quibus dicti priores provinciales sub pena suspensionis ab eorum officiis curam adhibeant diligentem; ceterum si quis frater inventus fuerit personam aliquam absolvisse a peccatis vel sententiis, dominis prelatis et superioribus reservatis, ulterius vigorem canonum penam graviori culpae debitam per presidentem suum subire indispensabiliter compellatur; si quis vero in scandalum ordinis contra ordinis inhibitionem praedicare vel confessiones audire presumpserit, vi statuti presentis sit ipso facto excommunicatus nec absolvi possit nisi a magistro ordinis vel per capitulum generale», MOPH 8, pp. 229-230.

12 P. DE LEón, Guía del Cielo, p. 590. Fray Pablo ha arreglado el pasaje evangélico del hijo pródigo, haciendo que el padre perdonara al hijo por su humillación. Evidentemente el propósito era el de inducir al religioso a realizar un acto profundo de humildad. Cristo, en cambio, quería demostrar con esa parábola la gratuidad del amor divino. Es por ello que el padre perdona a su hijo no por su arrepentimiento, sino porque simplemente había vuelto a su casa. La actitud de fray Pablo es sintomática del clima de culpabilización que impregna al cristianismo promovido por los reformadores. Como afirma Jean Delumeau, «la confesión fue una coacción de múltiples aspectos», La confesión y el perdón, p. 18.

${ }^{13}$ Las actas capitulares de 1489 determinan «pro serenitate conscientiarum fratrum volumus quod praelati laborent quantum poterunt ut confessiones suorum subditorum audiant vel quod ponant determinatos confessores asignando eis determinatam potestatem in absolutionem, reservando sibismetipsis haec quae sequuntur: scilicet absolutionem ab excomunicatione votorum esentialium videlicet in voto obedientiae a transgresione cuiuscumque praecepti in forma positi. Secundo in voto paupertatis quicumque aliquid quantamcumque parvum scienter et ex secundam personam quocumque modo, si votum castitatis fregerit», R. HERNÁNDEZ, «Actas de la Congregación de la reforma», A.D., I, p. 56. 
tos religiosos. En los conventos masculinos, el confesor natural era el prelado, que de ese modo podía vigilar la evolución espiritual y corregir la conducta de cada religioso $^{14}$. Esta última exigencia manifiesta la consideración que los reformadores tenían de la influencia que podían ejercer individuos reformados, dignos de su confianza, al ocupar este importante cargo.

Entre los dominicos de la Congregación de Holanda, los priores debían escuchar a los frailes en confesión cuatro veces al año. El resto del tiempo, se debían confesar con un confesor que siempre debía ser de la Orden ${ }^{15}$. Algo similar se establece en Toro para los castellanos ${ }^{16}$. A su vez mandan que «omnes fratres nostrae Congregationis, qui non sunt sacerdotes aut diaconi, sint sub regula et disciplina alicius Patris instituti a Priore, qui Magister Iuvenum dicatur, qui etiam confessiones ipsorum audiat, et hoc volumus quod inviolabiliter observetur in omnibus conventibus nostrae Congregationis». Los frailes laicos se encontraban, en consecuencia, bajo un régimen de control especial. Remarcar las diferencias entre esos religiosos y los hermanos sacerdotes fue una tarea continua de la reforma. En cierto modo las categorías sociales se repetían en la comunidad, así como las actitudes paternalistas y de dominación que estas diferencias conllevaban.

La satisfactio que seguía a continuación debía ser personal, voluntaria, discreta, suficiente y ajustada al pecador y al pecado. Este será a su vez obediente y se conformará a las exigencias de los confesores. No exagerará la penitencia, pero tampoco la atenuará. Los estatutos de la reforma insisten en la subordinación de las mortificaciones a la autoridad del superior. Las mortificaciones personales no debían ser nunca motivo para sustraerse a la disciplina colectiva.

Respecto al capítulo de las culpas, el maestro general Vicente Bandelli, en las actas del capítulo provincial de Peñafiel de 1504, ordena, «Praelatis ut has sanctas ordinationes faciant saltem quater in anno legi coram fratribus Congregationis et eas faciant observari et delincuentes puniant et ut fieri possit ordino quod quilibet Praesidens conventus saltem semel in septimana teneat capitulum

\footnotetext{
14 Por ello los reformadores se cuidan en ordenar «quod Superiores et Vicarii conventuum non praesumant subdelegare aliquem fratrem pro confessionibus audiendis tam fratrum quam secularium nec exponant fratres ordinibus suscipiendis nec mittent oficiales, quia non possunt nisi eis Priores vel superiores Praelati hoc exprese commitant», R. HERNÁNDEZ, «Actas de la Congregación de la reforma», A.D., I, p. 60.

15 Actes de la Congréation de Hollande, pp. 40 y 107.

16 Se determina «circa confessiones fratrum volumus quod Praelati audiant confessiones suorum subditorum saltem ter vel quater in anno et quando commititu alicui vel aliquibus audientiam confessionum suorum semper reservet sibi absolutionem sententiae excomunicationis maioris ab homine vel a iure latae et transgressionem cuiuscumque praecepti Praelatorum nostri Ordinis et ab omni proprietate et fractione voti castitatis in secumdam personam et si aliquando committatur absolutio supradictorum non differenter commitatur, sed solum aliquibus Patribus de quorum religione et honestate et conscientia confidant», R. HERNÁNDEZ, «Actas de la Congregación de la reforma», A.D., I, p. 88.
} 
de culpis et Reverendus Vicarius ac visitadores sint soliciti ut omnia debite observent» ${ }^{17}$. Una práctica que el prelado había quizás echado de menos en los conventos castellanos.

En definitiva, con la confesión de los pecados veniales en el capítulo de las culpas y de los mortales en el confesionario, los reformadores promovían la investigación y la valorización de la conciencia a fin de luchar contra el formalismo y el conformismo ${ }^{18}$. Asimismo, se desarrollaba y exteriorizaba una incertidumbre sobre sí mismo en cada religioso, a través de un intenso proceso de culpabilización ${ }^{19}$.

Sin embargo, los dominicos, siendo sacerdotes, estaban obligados no solo a frecuentar el sacramento de la confesión, sino también a procurarlo a los demás. Ante todo estaban encargados de confesar a las monjas de la Orden. En los conventos femeninos, las superioras no juegan ningún rol en este dominio, porque la confesión solo podía ser administrada por un sacerdote. ¿Pero los frailes en la cura monialium no pondrían en peligro el voto de castidad? Los superiores tomaron las precauciones oportunas ${ }^{20}$.

En efecto, los reformadores se encargaron de regular minuciosamente este asunto en los capítulos de Salamanca (1489), Toro (1493), Piedrahita (1495) y Ávila (1496). Con el fin de evitar cualquier tipo de abuso, se mandaron a los frailes «quod nullus Prior possit manu propia disciplinare vel carceri mancipare tales sorores, sed commitat hoc Matri ipsarum. Confessores ideo nullo modo se impediant cum illis, nisi de his quae ad forum penitentiae pertinent» ${ }^{21}$. Asimismo «sub poena gravis culpae mandamus quod nullus fratrum accedat ad monasteria quarumcumque monialium sine licentia sui Praelati vel Praelatorum ad quos declinaverint» ${ }^{22}$. La repetición de esta norma a lo largo de todo el siglo

17 R. HERnÁNDEZ, «Actas de la Congregación de la reforma», A.D., II, p. 102.

18 Delumeau considera que se trata de una práctica común a toda la cristiandad católica inducida por el miedo: «L'obsession de la confession "exacte" est certainement l'une des grandes causes qui ont conduit l'Eglise romaine à l'utilisation d'une pastorale de la peur. Il fallait de toute nécessité faire comprendre aux fidèles la gravité des silences et des demi-aveaux dont ils se rendaient coupables au "tribunal de la pénitence". L'omission volontaire constituait un "sacrilège" punissable de l'enfer des lors qu'on dissimulait un péché mortel», J. DelumeAu, Le péché et la peur. La culpabilisation en Occident XIII-XVIII siècles, París, 1983, p. 526.

19 Cfr. José María Soto RÁBAnOs, «Derecho canónico y praxis pastoral en la España bajomedieval». Monumenta juris canonici, series C: Subsidia, vol. 7 (1985), 595-617; Louis BRAECKMAN, S. J. Confession et communion au Moyen Age et au concile de Trente, 1971.

${ }^{20}$ En 1491, la congregación dominica de Holanda confirma la separación de los frailes que pertenecen a casas de religiosas. Se exige solamente que esos religiosos vuelvan dos veces al año a sus casas de origen, de las que continúan dependiendo. Es por ello que en Poissy Jean Clérée quitó a las religiosas sus padres confesores, para reemplazarlos por dominicos reformados. Las monjas «demeurent désolées». J. M. LE GALL, Le moines..., p. 332.

21 Ibíd., p. 63.

22 R. HeRnÁnDEZ, «Actas de la Congregación de la reforma», A.D., II, p. 89. 
— «de non eundo ad monasteria monialium et de cellis non intrandis»— si bien ponía en evidencia la dificultad para hacerla respetar, también dejaba en claro la constancia y el apego que profesaban los observantes a un ideal que se les antojaba irrenunciable ${ }^{23}$.

$Y$ es que el ejercicio de la pastoral confesional que desarrollaron los frailes entre esas mujeres no se reducía a la administración del sacramento, ya que éste era sobrepasado por una asistencia espiritual más amplia, producto de una tradición que se remontaba al nacimiento de la Orden y que fue practicada por el mismo Domingo de Guzmán ${ }^{24}$. Entre los dominicos de la reforma el resultado de esa experiencia condujo durante la primera mitad del siglo XVI a la elaboración de tratados de teología moral y espiritual dirigidos a sus devotas seguidoras.

Fray Domingo de Valtanás, afiliado al convento de San Esteban de Salamanca y prior del de Sevilla, compuso, en 1557, Exposición sobre el estado y velo de las monjas. Se trata de un pequeño libro dedicado a la priora y fundadora del convento de Baena, doña Brianda de la Cerda. En medio de un mar de elogios al estado religioso, fray Domingo intenta aclarar un asunto que a mediados del siglo XVI inquietaba los claustros femeninos. Se trataba de la posibilidad que tenían las religiosas de elegir o no confesor. Coincidiendo con el pensamiento general de los superiores de la Orden, Valtanás da una respuesta categórica a este asunto, las monjas de la Orden, «para la quietud del anima y del cuerpo, y para el bien del monasterio, muy mejor es que tengan confesores señalados, con tanto que tres, o quatro vezes en el año tengan libertad de confesarse con quien en devoción tuvieren ${ }^{25}$. De hecho, a partir de 1563 , los capítulos provinciales indican por primera vez los confesores correspondientes a cada uno de los conventos femeninos bajo su jurisdicción, ejerciendo un control directo sobre las casas femeninas, como no había sido posible hasta entonces ${ }^{26}$.

23 En 1504, el maestro general Bandelli en visita canónica a la Provincia de España, definió con severidad el comportamiento que los frailes de la Orden debían seguir con las monjas que asistían en el confesionario. Ordena que todos «in virturte Spiritus Sancti et sanctae obedientiae quatemus nullus audeat accedere ad loquendum cum monialibus, sint quaecumque, vel eis scrivere aut munera mitrere vel ambassiatas aut res suas apud eas retinere vel ab eis litteras aut res alias recipere sine licentia Praelati. Vicarii etiam et confessores monialium sint admoniti quod est censura apostolica, si ingrediatur monasteria nisi in casibus in Constitutionibus monialium expraesis vel nisi habeant privilegium», R. HERNÁNDEZ, «Actas de la Congregación de la reforma», A.D., II, pp. 95 y 136.

${ }^{24}$ H.-M. ViCAIRE, «Dominique (saint)», Dictionnaire de Spiritualité, t. 3, París 1957, cc. 15191532.

25 Hemos consultado el volumen guardado en la Biblioteca Nacional de España, R-39112.

${ }^{26}$ Se trataba de una respuesta de los dominicos de Castilla a las indicaciones dadas por el Concilio de Trento que en ese mismo año había en el décimo decreto de la constitución Religiosos y Monjas había establecido: «Pongan los Obispos y demás superiores de monasterios de monjas diligente cuidado en que se les advierta y exhorte en sus constituciones, a que confiesen sus pecados a lo menos una vez en cada mes, y reciban la sacrosanta Eucaristía para que tomen fuerzas con este socorro saludable, y venzan animosamente todas las tentaciones del demonio. Preséntenles también el Obispo y los otros 
Finalmente, entre 1593 y 1595, los capitulares elaboraron unas instrucciones dirigidas a los confesores y a las monjas, con el fin de regular algunos detalles del ejercicio de la pastoral confesional de los frailes entre las religiosas ${ }^{27}$. En ellas se instaba a los confesores a procurar «con el buen ejemplo de sus personas, el aprovechamiento espiritual, de las dichas religiosas, y el aprovechamiento de los conventos que tienen a su cargo». A esos frailes, que en general no vivían en los conventos masculinos - ya sea porque en la ciudad donde estaba instalado el convento femenino no existían o porque, en virtud de la asistencia a las monjas, debían obediencia a la superiora del convento femenino- los superiores les exhortaban a ajustarse «en quanto les fuera posible con la observancia Regular que deben a sus leyes y profesión». Se les mandaba además «que no tengan devociones ni amistades particulares con Religiosa alguna. Y para que esto se haga, mejor se ordena y manda a las madres Prioras, o perladas de los dichos conventos, que tengan ellas las llaves de los confesionarios, por la parte interior del convento: y no permitan que se abran, sino en tiempos y ocasiones, que se entienda que es para confesar, o para consuelo espiritual de las Religiosas». Por su parte, las madres Prioras no debían admitir «pláticas, ni visitas, ni devociones, ni tratos de hombres, de cualquier estado, condición o calidad que sean, ansi seglares, como religiosos o clérigos» Las monjas sólo podían relacionarse con familiares de hasta un tercer grado de consanguinidad y muy de vez en cuando. «Por lo que tocase a hablar con frailes de nuestra religión, queremos que sea guardando las actas de nuestro Capítulos y las ordenaciones que hubiere acerca de las visitas en los monasterios y Conventos».

En síntesis, a lo largo del siglo XVI, la experiencia había reforzado la sospecha y con ella prevención. El vínculo de un fraile con una monja quedaba, por lo tanto, reducido al de un sacerdote con un fiel, de un confesor con un penitente, de un predicador con un oyente, de un visitador a una visitada, es decir profundamente jerarquizado. Formalismo deudor del miedo a un pecado que tenía graves consecuencias. En efecto, todo fraile observante sabía muy bien «que el pecado con las religiosas es simple fornicación y adulterio, porque son expresamente esposas de Jesucristo; y más que es estupro, que comúnmente son vírgenes, y sacrilegio e incesto. Así que toda las especies de las lujurias comete el que llega a monja, y ella de todos es participante» ${ }^{28}$.

Del mismo modo, ya que la dirección espiritual así como el gobierno de las

superiores, dos o tres veces en el año, un confesor extraordinario que deba oírlas a todas de confesión, además del confesor ordinario. Mas el santo Concilio prohíbe, que se conserve el Santísimo Cuerpo de Jesucristo dentro del coro, o de los claustros del monasterio, y no en la iglesia pública; sin que obste a esto indulto alguno o privilegio».

27 Se trata de las Ordenanzas para las Religiosas promulgadas por el Capítulo de Segovia de 1597 y la Institución a los Confesores de Monjas del Capítulo de Ávila de 1599. AGOP, XIII, 26045, 2.

28 P. DE LEÓn, Guía del Cielo, p. 555. 
hermanas terciarias de la Orden correspondía desde siempre a los frailes, las disposiciones dedicadas a regular las relaciones de los frailes con esas mujeres fueron, asimismo, detalladas y puntillosas. Se pretendía, por un lado, garantizar y corroborar la vocación religiosa de estas mujeres — según los parámetros de la observancia - y, por otra, evitar cualquier ocasión de pecado, para atender al perfecto cumplimiento de la virtud y del voto de castidad de los frailes.

La normativa se justificaba sobre todo a raíz de los supuestos problemas que habría causado con anterioridad a la reforma la relación con las terciarias cuya «indiscretam receptionenm ac conversationem magna fratum conturbatio ac secularium scandalum et murmuratio in dies oboritur». Por ello se ordena que solamente se de el hábito a mujeres mayores de cuarenta años «bonae famae, honestatae conversationis et quae propriis sumptibus valeat sustentari». Y si estas religiosas no conservaban la compostura y discreción debida «quancitius nostro habitu exuatur et ab caeterarum consortio penitus separentur». A los frailes, a su vez, se les conmina a que no mantengan largos coloquios con esas mujeres «etiam si sit pater ipsarum spiritualis, nisi circa confessiones sacramentales, gravantes insuper conscientias Praelatorum ne in huismondi licentiis sint faciles ad dispensadum». Por último, los confesores de las religiosas del «tertio habitu possint amoveri a Prioribus conventuum illorum locorum, in quibus tales sorores sunt, et ab aliis loco eorum substituti. Ipsi tamen priores non sint confessores earum» ${ }^{29}$.

Similares temores manifiestan los reformadores hacia todo el género femenino. En consecuencia, para hacer frente a la dificultosa administración del sacramento de la confesión se prohíbe a los frailes «ne quis confessionem mulierum audita, nisi habuerint originem et sint honesti et graves moribus. Verum est quod si quis aetatis minoris mitteretur extra ad praedicandum, possit audire dummodo sit honestae conversationis, et prohibeo ne confessiones mulierum audiantur, nisi in plena luce. Caveat attamen Praelatus ne exponat ad audiendas confessiones [mulierum] leves et periculosos vel eos qui sunt notati apud omnes de inhonestate, et etiam caveat ne promoveat fratres ad ordines vel ad audientiam confessionum secularium, sine expressa licentia Vicarii Generalis».

En fin, la confesión, al obligar a un trato íntimo con mujeres y con seculares, era un asunto peligroso que no debía ser confiado a cualquier fraile, ya que ponía en peligro la vida virtuosa del religioso. Si embargo el ejercicio de la pastoral de la confesión no sólo preocupaba a los reformadores porque era peligrosa para los hermanos, sino porque sabían que su administración, confiada a individuos inexpertos o incapaces, era un asunto peligroso y dañino sobre todo para aquellos que se acercaban a ser liberados del peso de sus culpas ${ }^{30}$.

29 R. HERNÁNDEZ, «Actas de la Congregación de la reforma», A.D., I, pp. 57 y 63.

$30 \mathrm{Tal}$ como lo expresan las actas capitulares, «ubi non solum est dedecus Ordinis sed in periculum 
No obstante lo dicho hasta aquí, la confesión, dispositivo de socialización y de control de los miembros de la propia comunidad o de comunidades ajenas, era entre los frailes reformados antes que nada una acción purificante y, en consecuencia, el medio ineludible sin el cual no se podía participar a la comunión sacramental $^{31}$.

\section{COMULGAR CON PERIODICIDAD}

La precisión de las respuestas que fray Juan de Salamanca en 1478 había dado en la controversia mantenida con Pedro de Osma respecto al sacramento de la confesión había puesto al descubierto la importancia que los dominicos otorgaban a esta práctica ${ }^{32}$. No solo, allí se había explicitado el superior conocimiento que los dominicos tenían de la teología sacramental, dejándose en claro la relación que existía entre la confesión, la comunión eucarística y el ministerio sacerdotal ${ }^{33}$.

etiam vertitur animarum, ideo diligentia ocurrendum est». Por eso prohíben que «ne aliquis ad audientian confessionum exponatur nisi sit suficienter instructus in censuris ac casibus conscientiae, agravans super hoc conscientiam Reverendi Vicarii Generalis et Praesidentium conventuum, et si qui talis sint iam expositi volo quod habeantur pro expositis et, ut in hoc aliqua observetur diligentia, ita ordino ut quicumque sunt exponendi ad audientiam confessionum Reverendus Vicarius et Praesidens conventus cum lectore et duobus aliis peritis Patribus diligenter examinent et agravo conscientias, si non idoneos iudicarent et exponerent», R. HERNÁNDEZ, «Actas de la Congregación de la reforma», A.D., II, p. 103.

31 Devotos seguidores de los Padres de la Iglesia, los observantes sabían que San Agustín había advertido que «quien recibe el misterio de la unidad y no tiene el vínculo de la paz no recibe un misterio salvador en favor suyo, sino un testimonio contra sí mismo. Si vosotros sois el cuerpo de Cristo y sus miembros entonces vuestro mismo misterio reposa sobre la mesa de la Eucaristía. Vosotros debéis ser lo que veis y debéis recibir lo que sois», S. Agustín, Homilía 272. Por otro lado, Santo Tomás había afirmado que las faltas impiden el efecto del gozo actual, del fervor espiritual, del deleite o del amor actual, tan importante para unos hombres que vivían una vida magra en deleites, Suma Teológica, III, q.79, a.2.

32 Nos ahorramos la exposición completa del juicio a Pedro de Osma, para ello reenviamos al artículo que sobre Pedro de Osma publicó en su momento M. Menéndez Pelayo, Historia de los heterodoxos españoles, II, 1947, pp. 367-391.

${ }_{33}$ Cfr. R. HERNÁNDEZ, La confesión y las indulgencias: prerreforma y tradición, Salamanca, 1978. No hay dudas, por lo tanto, que los dominicos, incluso antes de la reforma, eran unos celosos custodios del valor sacramental de la eucaristía. En 1482 los frailes de San Esteban de Salamanca habían vuelto a dar prueba de ello al denunciar a un universitario, esta vez un alumno que había formulado proposiciones consideradas heréticas referentes a la presencia de Cristo en la eucaristía. Situación que además «ofreció otra ocasión en que se reconociese lo mucho que siempre ha celado la pureza de las doctrinas en el convento dominico». Se trataba nada menos que de una muestra de observancia y de ortodoxia de los frailes de San Esteban ante los intelectuales de la ciudad. "Causó escándalo en muchas personas doctas esta proposición, y para decidir que se debía sentir en ella, en 13 de diciembre (de 1482) juntó Claustro don Gutierre de Toledo (hijo de don García Álvarez de Toledo, duque de Alba), maestrescue$l a »$. El religioso fue examinado y corregido por una comisión compuesta por fray Diego de Deza y fray Diego de Betoño, ambos religiosos de San Esteban. J. Cuervo, Historiadores, p. 495. 
Santo Tomás de Aquino, a quien los dominicos castellanos seguirían con fervor desde fines del siglo XV, había afirmado que este sacramento representaba la pasión de Cristo, «por eso los efectos que la pasión de Cristo hizo en el mundo (la redención), este sacramento los hace en el hombre» ${ }^{34}$. De allí que el movimiento reformista, haciendo gala de su típico existencialismo espiritual, más que teorizar sobre el valor del sacramental de la eucaristía, animó a los religiosos y religiosas a recibir con frecuencia el pan consagrado. Los frailes sacerdotes, en virtud de su estado, estaban obligados a celebrar diariamente la Eucaristía, mientras que los frailes laicos estaban comprometidos por las normas de la Congregación de la Observancia a comulgar «de quince a quince días. En el Adviento y en la Cuaresma lo podrán hacer todos los domingos, menos el domingo cuarto de Adviento y el de los Ramos. Si en algún momento se difiriera la comunión por razón de la reverencia de alguna fiesta, debe haber un intervalo de cinco o seis días entre ambas comuniones» ${ }^{35}$. Frailes que no eran sacerdotes y monjas reformadas debían comulgar al menos cada dos semanas. De este modo, la norma del concilio de Vienne era cómodamente sobrepasada. No obstante, incluso ante los sacramentos, las jerarquías sociales se mantenían. La efusión de la gracia a través de la Eucaristía era más grande en un sacerdote que en un laico o en un profeso que en un novicio.

Por otra parte, la comunión frecuente exigida a los reformados subraya cuánto la imitatio Christi no era suficiente. Los religiosos a través de la hostia consagrada aprovechaban de los méritos del sacrificio de Jesucristo. Sin su oblación, reiterada en la Eucaristía, sin la gracia expedida por el sacramento, el fraile no se podía salvar. La frecuentación asidua de la Eucaristía como de los otros sacramentos era la manifestación de una búsqueda casi insaciable de la gracia, constantemente solicitada y absorbida. La reiteración de la comunión manifiesta, asimismo, un apetito de comunicación con un Dios invisible pero presente y salvador. En el camino de la salvación, allí está Cristo que, tal como el buen samaritano, aplica sobre las llagas de los pecadores la medicina y el remedio de sus sacramentos. Esta metáfora farmacéutica era frecuentemente utilizada para calificar los sacramentos, sus efectos y su eficacia ${ }^{36}$.

\footnotetext{
34 Suma Teológica, III, q.75, a.1.

35 La disposición corresponde al Capítulo de Ávila de 1496, (5, 12). R. HernÁNDEZ, «Actas de la Congregación de la reforma», Archivo dominicano, I, p. 133.

36 Refiriéndose a la eucaristía, dice Santo Tomás que «debe aplicarse la medicina donde está la enfermedad. Por tanto, fue conveniente que Dios, mediante signos corporales, procurara al hombre la medicina espiritual. Porque si se le ofrecieran las cosas espirituales desnudas de corporeidad, su ánimo no se interesaría por ellas, por haber quedado tan inclinado a las cosas corporales». Suma teológica, III. ${ }^{\text {, }}$ q. 61 . El redescubrimiento de la Patrística que hicieron las reformas habría coadyuvado a una definición más acorde de las prácticas sacramentales a las exigencias de los tiempos. San Ignacio de Antioquia, uno de los más antiguos Padres de la Iglesia, llamaba a la Eucaristía «medicina de inmortalidad, antídoto para no morir, sino vivir por siempre en Cristo Jesús» (Ef 20,2). El Concilio de Florencia, a su vez, había precisado el valor santificante de este sacramento. Al enseñar su eficacia res-
} 
Nos podemos preguntar en qué medida el rechazo al nominalismo que manifestaba la reforma dominica — que por otro lado hizo del tomismo su bandera- no favorecía la práctica frecuente de la comunión. Para la corriente realista, en la que fue elaborado el dogma de la transustanciación, el conocimiento procedía de los sentidos. Esta actitud incitó la repetición de la cena, la necesidad de ver, de tocar y de absorber. Por otro lado, los frailes habían aprendido que uno de los principales efectos de la Eucaristía era deleitar («delectat», dice Santo Tomás). Así como la comida material deleitaba al cuerpo, este manjar espiritual deleitaba el alma ${ }^{37}$. La gracia de la Eucaristía, gracia cibativa, entre otras cosas produce en acto el sustentar la vida espiritual, el aumentarla, el desarrollarla, el reparar las fuerzas que se pierden, dando mayor gracia y mayor caridad habituales. Pero más allá de la actualidad del hábito está la actualidad del acto en el que prorrumpe el hábito poseído. La Eucaristía debía producir en las almas el amor a Dios, aquél que, según fray Pablo de León, «hace al hombre salir de sí mismo y traspasarse en Dios, y deja el hombre de ser suyo y es de Dios, y ya no es el que era, sino es ya Dios porque es transformado en él» ${ }^{38}$.

La afirmación por la Iglesia de la presencia real del cuerpo de Cristo en la hostia durante el sacrificio de la misa convierte este cuerpo en el eje del mundo. El fraile no tiene esperanza más hermosa que la de comer este cuerpo divino, puesto que la Eucaristía es el viático indispensable, la garantía de no sucumbir al mal, la seguridad de salvarse. Desde medidos del siglo XVI la controversia sacramental contrarreformista concedió prioridad a la imagen de la presencia real de Cristo en la hostia sagrada, en competencia con la imagen del cuerpo mortificado del Cristo de la Pasión, tan cultivado hasta entonces. Inusitadamente, numerosos escritores dominicos - entre ellos fray Domingo de Valtanás con su Apología de la frecuentación de la sacrosanta eucaristía, y comunión, compuesta en 1558 - dedicaron su pluma a avivar la estima y señalar los beneficios obtenidos tras la consumición del cuerpo sacramental de Cristo $^{39}$.

pecto de la vida espiritual del que comulga, señala dos efectos propios de todo alimento y los aplica a la vida de la gracia: el de sustento, fortalecimiento y crecimiento por un lado, y el de prevención y curación medicinal. «Todo el efecto que la comida y la bebida materiales obran en cuanto a la vida corporal, sustentando, aumentando, reparando y deleitando, este sacramento lo obra en cuanto a la vida espiritual». Bula Exultate Deo, Decreto para los armenios, D 698. Así, la Eucaristía aumentaba la gracia santificante, perfeccionando más que ningún otro sacramento la vida espiritual del cristiano. Con la gracia, aumentaban también las virtudes infusas, particularmente la caridad. Junto con esto, la Eucaristía destruye los pecados veniales y preserva de los mortales.

37 Suma Teológica, III, q.75, a.2.

38 P. DE LEÓN, Guía del cielo, estudio preliminar y edición de Vicente Beltrán de Heredia, Barcelona, 1963, p. 176.

39 D. DE VALTANÁs, Apología sobre ciertas materias morales en que hay opinión; y Apología de la comunión frecuente, estudio preliminar y edición de Álvaro de Huerga y Pedro Sainz Rodríguez, Barcelona, 1963. Una guía sobre las publicaciones de los dominicos en los siglos XVI y XVI referidas a este tema en J. Simón Díaz, Dominicos de los siglos XVI y XVII: escritos localizados, Madrid, 1977. 
Es cierto que el crecimiento de la devoción eucarística a lo largo del siglo XVI tocaba al conjunto de la Iglesia, pastores y fieles. Sin embargo la reforma de los religiosos parece ser el vector motor de una evolución cultural que se generaliza más tarde fuera del mundo de los consagrados ${ }^{40}$.

\section{INFLIGIR AL CUERPO LOS CASTIGOS QUE SE MERECE}

La confesión periódica de los pecados y la comunión sacramental frecuente no eran suficientes para satisfacer a los frailes reformados. Tampoco se trataba de elementos que los distinguiera particularmente del resto de los cristianos. Esenciales, los sacramentos necesitaban un medio adecuado para operar con plenitud la recepción de la gracia purificante que facultaba, a su vez, para contemplar la verdad.

La práctica de las virtudes y la observancia de los votos hacían de los frailes los depositarios de la plenitud de la gracia que, mediante su actividad apostólica, se derramaba sobre la humanidad. Por otro lado, ser un consagrado, haberse hecho fraile, revestía una importancia capital a los ojos de los hombres y de las mujeres del siglo XV y XVI ${ }^{41}$. Prometer ser obediente, pobre y casto el día de la profesión era un acto irrevocable y perpetuo. «La perfección del religioso consiste en la guarda de los tres votos substanciales de pobreza, obediencia y castidad», enseñaba el reformador dominico fray Juan de la Cruz ${ }^{42}$.

El rigor de los tres votos, tan estrechamente practicados, la oración litúrgica con los maitines a media noche, el régimen de comidas y vestido mortificante, el silencio y la vigilancia escrutadora de los superiores, bastaba esto para que el fraile comprendiese que, al hacer la profesión en el convento, se comprometía de por vida a vivir como penitente. Pero, si alguna vez le quedaba alguna duda, otras observancias penitenciales, se encargarían de grabar en su carne y en su espíritu que su vocación era el sacrificio. En efecto, la profesión religiosa fue concebida por los observantes como una vida de continua penitencia.

40 Vid. A. VAucheZ, Le lä̈cs au Moyen Âge, 1987, pp. 259-264.

41 Numerosos son los estudiosos que han revelado el interés que en la sociedad castellana despertaba el mundo de los religiosos. En efecto su misma existencia y reflorecimiento a lo largo de los siglos que tratamos se debe a la vinculación funcional con dicha sociedad. Cfr. J. GARcía Oro, La reforma de los religiosos españoles en tiempo de los Reyes Católicos, Valladolid, 1969, pp. 91-126; A. RUCQUOI, «La réforme monastique en Castille au XV siècle: une affaire sociale», en H. DuBoIs, J. C. HocQuET y A. VAUCHEZ (comps.), Horizons marins, itinéraires spirituels, 1987; B. BENASSAR, La España de los Austrias (1516-1700), Barcelona, 2001, p. 117.

42 J. DE LA CRUZ, Diálogo..., p. 438.

Hispania Sacra, Estudios de Edad Moderna, 58

117, enero-junio 2006, 39-67, ISSN: 0018-215-X 


\section{LA CARNE MORTIFICADA}

El seguimiento de Cristo y la búsqueda de la anulación de si mismos pasaban en estos espíritus exigentes por la mortificación del cuerpo. Fray Alonso Valentín "era pacientísimo en sus enfermedades, y estaba tan enseñado a huir de regalo, y tan bien hallado con el maltrato de su cuerpo, que aún en ellas aborrecía todo lo que huele a delicadeza. Yéndole a visitar un médico en una que había contraído del trabajo y mal tratamiento, y pidiéndole la mano para tomar el pulso, le respondió que no tenía calentura, y no hubo remedio de dársela. Y replicándole, dijo al enfermero: Cierto, hermano, ya este médico podía estar en su casa y no venir aquí, que los frailes no tenemos necesidad de tanto regalo y cuidado, ni nuestro estado quiere esta manera de proceder ${ }^{43}$. Todo lo que pueda parecer complacencia o debilidad para con el cuerpo se considera fuente de malos pensamientos. El cuerpo, por lo tanto, debe ser vigilado y atado corto sin cesar ${ }^{44}$.

Todos los reformadores insistieron sobre la dimensión mortificante de la vida religiosa. En los orígenes, esta fue concebida como una expiación aplicable a los pecadores arrepentidos, con el mismo valor que la peregrinación. Esta concepción inicial dejó su huella ya que la vida regular se convirtió en la penitencia por excelencia. En efecto, «estado de religiosos es estado de penitentes» y lo es de tal modo "que a quien entra en religión el derecho conmuta cualesquiera trabajosas penitencias a que esté obligado o merezca por sus crímenes» ${ }^{45}$.

Cuenta fray Pablo de León que "estaba un religioso que había sido muy abstinente y trabajado en las cosas de la orden, y a la muerte dijéronle algunos padres: Ved que vuestras abstinencias y trabajos os han traído tan presto a la muerte. Respondió el buen viejo: Y si esto no fuera, hijos ¿en qué estribara $y o ?{ }^{46}$. Las mortificaciones, abstinencias y renuncias eran elementos irrenunciables de un religioso que tratara de aproximarse al Cristo de los dolores para compartir sus tormentos ${ }^{47}$. La disciplina corporal reflejaba la disciplina de vida

\footnotetext{
${ }^{43}$ Fraile del convento de San Esteban de Salamanca enviado, junto a Domingo de Montemayor, a reformar los conventos valencianos. Historiadores..., III, p. 572-573. Sobre la reforma en Valencia véase A. RoBles, «La reforma entre los dominicos de Valencia en el siglo XVI», Corrientes espirituales en la Valencia del s. XVI (1550-1600). Actas del II Simposio de Teología Histórica (20-22 abril 1982), pp. 183-203.

44 Desde el siglo II. ${ }^{\circ}$, el vocablo paenitentia había sido reservado para traducir el griego metanoia, o sea la invitación a convertirse. De este modo, estado religioso, penitencia y conversión se transformaron en términos intercambiables. Se trata, por lo tatno, de una práctica reasumida por todos los religiosos en Occidente a lo largo del siglo XVI. Cfr. J. GÉLIs, «El cuerpo, la Iglesia y lo sagrado», en George Vigarello (coord.), Historia del Cuerpo, vol. 1, Madrid, 2005, pp. 58-61.

45 J. DE LA CRUZ, Diálogo..., p. 430.

46 P. DE León, Guía del Cielo, p. 150.

47 Introducida por la reforma, el ansia de una vida penitencial más austera era patrimonio general todos los religiosos observantes. En su Oratorio de religiosos y exercicio de virtuosos, compuesto en
} 
que se había profesado, la que a su vez reposaba sobre las Escrituras. Ahora bien, ¿entre los religiosos las mortificaciones corporales no se llamaban acaso disciplinas? Se trataba de castigos numerosos y muy duros al decir de Juan de la Cruz, "tantas disciplinas como los religiosos acostumbran, dadas por sus propias manos, y otras, que más se sienten como es cosa natural, dadas por manos ajenas ${ }^{48}$.

Algunos reformadores, indujeron a sus comunidades a exageraciones en la aplicación de estas mortificaciones. Los seguidores de la Beata de Piedrahita, por ejemplo, pretendían que todos lo frailes durmieran sobre tabla, rechazando los colchones de lana, autorizados por las Constituciones, que vistieran hábitos cortos y estrechos y que adoptaran la descalcez. La Provincia, en el capítulo de 1508 , recordó a los frailes que «in observatione Regulae et Constitutionum religionis observantia consistit» y por ello prohibió todas esas prácticas ascéticas que fueron tenidas como innovaciones. Asimismo se dejó en claro la importancia de los estudios en la Orden, por ello se recordó a los priores el valor de las dispensas para los que estudiaban y se instó a que los más preparados se presentaran a las oposiciones universitarias de teología para poder difundir la doctrina de Santo Tomás. Fruto de la enseñanza de esa doctrina, los excesos del grupo de Piedrahita fueron considerados rasgos de soberbia y de seguridad, de hipocresía y jactancia ${ }^{49}$.

Sin embargo, aunque la Provincia logró el aislamiento y desaparición del grupo de Piedrahita, muchos religiosos nunca se contentaron con las exigencias de la vida regular impuesta a sus comunidades a partir de la disolución de la Congregación de la reforma. Eran hombres que «nunca se satisfacen de sí mesmos, y si no van creciendo en virtud, se tienen por desmedrados en ella. Y éstos son, en fin, sus cuidados, crecer, aventajarse, mejorarse, y poniendo en olvido el bien que han hecho, darse apriesa a otros mayores, como si de nuevo comenza$s e n{ }^{50}$. Estas exigencias y continuas insatisfacciones revelan los límites de una espiritualidad ascética que en muchos casos generaba en esos individuos verdaderas crisis de ansiedad y angustia ${ }^{51}$. Fray Juan Hurtado, personaje paradigmá-

1544, el franciscano Antonio de Guevara (1480-1545), obispo de Mondoñedo, amonestaba a todos aquellos que querían entrar en la vida religiosa sin un espíritu de sacrificio diciendo: «Tu que vienes a la religión, has de pensar hermano mío, que veniste a ofrecer y a sacrificar al Señor, no solo la hazienda, más aún el anima, no solo el anima más aún la vida, y no solo la vida más aún la honra: de manera, que digas como el apóstol, vivo yo más ya no yo, vive en mi aquel que murió por mi (...) acá en la religión, has de ofrecer hermano mío a tu Dios las manos para trabajar, los ojos para llorar, el cuerpo para ayunar, la boca para rezar, y el corazón para le amar», Biblioteca Nacional de España, R. 3189058, fol. 38 .

48 J. DE la Cruz, Diálogo..., p. 430.

49 R. HERNÁNDEZ, «Actas de los capítulos provinciales», A.D., VII (1986), pp. 21-23.

${ }^{50}$ Historiadores..., II, p. 536.

51 Cfr. J. Mirena AldAY, «L'ansia nella vita consacrata», Claretianum, CLIII, 2003, pp. 71-106.

Hispania Sacra, Estudios de Edad Moderna, 58

117, enero-junio 2006, 39-67, ISSN: 0018-215-X 
tico para los dominicos castellanos, las padecía con frecuencia. En 1519, tras llevar más de veinte años de una vida religiosa que había intentado vivir con sobriedad, "andaba descontento de su vida, dando trazas en otra que fuese de mayor rigor, de mayores penitencias, de mayor caridad y perfección. Y poniendo los ojos en los primeros fundadores de esta santa Orden le pareció que se quedaba él tan atrás que desmerecía el nombre de fraile de Santo Domingo ${ }^{52}$.

Numerosos frailes, tanto de los conventos de Piedrahita como de San Esteban, acompañaron a fray Juan Hurtado por esas «sendas más estrechas que las ordinarias» en su proyecto de dar vida a las comunidades de estricta observancia de Talavera, Atocha y Ocaña. Fundaciones que estuvieron llenas de austeridades, de mucho trabajo en la huerta, de mucha oración y de «muchos azotes y disciplinas» ${ }^{53}$. Paradójicamente esas penitencias fueron el secreto del éxito de esas comunidades: "Un hombre del lugar, de edad de treinta años, pidió el hábito de la Religión, y dentro de pocos días que lo tuvo, vencido del trabajo, lo dejó, y salió diciendo de los frailes tales cosas, que movieron al pueblo a una devoción nunca pensada ni vista. Aquellos hombres (decía el novicio) ni comen, ni duermen, ni beben; toda su vida es disciplinas y azotes. Son el prodigio del mundo, no puede con aquella vida durar ni vivir hombre sin milagro» ${ }^{54}$. Asombro, pero también admiración e incluso estima despertaba en los laicos de la época ese estilo de vida. De allí que la observancia fuera ante todo una expresión social e incluso una exigencia de los laicos hacia los religiosos.

Las austeridades fueron una necesidad perenne del fraile observante. En una sociedad impregnada de miedos, que incitaba a los hombres continuamente a la violencia, la penitencia y las maceraciones se convirtieron en un medio psicológico imprescindible para refrenar las pasiones, a su vez que ayudaba a integrar y a motivar la vida de esos hombres ${ }^{55}$. "Todo el carecimiento de deleites que se tienen por la castidad, todos los trabajos y aflicciones de la pobreza, todo el cansancio de las obras penosas que se hacen por la obediencia, si el religioso quiere y se esfuerza, le convidan y le dan empellones que vaya a conversar con Dios para hallar en él santos placeres, verdaderas riquezas y seguro contentamiento ${ }^{56}$. Por ende, el cumplimiento de los votos, sostenido por una vida austera y mortificante, permitían al fraile simultáneamente vencer el mundo y ganarse el paraíso. Fray Juan de la Cruz lo formulaba con simplicidad: «El

52 Historiadores..., III, p. 536

53 Historiadores..., III, p. 537

${ }^{54}$ Historiadores..., III, p. 540.

55 Miedos escatológicos, pero sobre todo el miedo a la salvación y, en consecuencia, una obsesión por el pecado caracterizaron la cultura de los castellanos de los siglos XV y XVI. Vid. J. DeLUMEAU, El miedo en Occidente, Madrid, 1989, pp. 9-49; A. RUCQUOI, «Mancilla y limpieza: la obsesión por el pecado en Castilla a fines del siglo XV», en Os «últimos fins» na Cultura Ibérica (XV-XVIII), Rev. Fac. Letras, Lenguas e Literaturas, Anexo VIII, Porto, 1997, pp. 113-135.

56 P. DE LEÓn, Guía del Cielo, p. 488. 
ejercicio de la disciplina corporal ha de ser nuestro principio y la virtud nuestro fin ${ }^{57}$.

Por otro lado, las disciplinas, antes y después de la disolución de la Congregación de la reforma, fueron exaltadas a coro por todos los frailes como un medio extraordinario para lograr la perfección. Las mortificaciones del cuerpo fueron promovidas por una lectura ascética del neoplatonismo o del estoicismo imperante. La divisa estoica es «soporta y abstiénete». Desde esta óptica, la abstinencia no se limitaba a la prohibición de comer. En efecto, ya que el voto de castidad prohibía a los frailes todo acto carnal, la privación de la carne resultaba un buen medio para respetar la abstinencia sexual ${ }^{58}$.

En el alba de la Edad Moderna, a través de una perseverante campaña de moralización de los claustros — que precedía la de la sociedad entera- los dominicos se preocuparon por recordar que, «muchos remedios dan los sanctos para subjetar la carne al spiritu. Como la oración común y particular ferviente. La lection sancta y de cada día. La disciplina, la vestidura áspera. El recogimiento de los sentidos. El escusar la conversación estrecha y no necesaria de mugeres. Mas sobre todo, mas aprovecha la abstinencia y comida templada. Porque como dize el sabio Salomón. Quitados los tizones se apaga el fuego» ${ }^{59}$. Se trata, por lo tanto, de un instrumento de ascesis ${ }^{60}$. Para Pablo de León el ayuno se ordena para cuatro cosas: refrenar la concupiscencia de la carne, elevar el espíritu, "porque mejor el entendimiento se levante a cumplir las cosas altas y divinas y sotiles», y para expiar los pecados. En fin, «el ayuno reprime los vicios, levanta el entendimiento y por él dan todas las virtudes y premios» ${ }^{61}$.

57 J. DE LA CRUZ, Diálogo..., p. 440.

58 En gran parte se trata de un retorno a los valores más caros de los religiosos de la Alta Edad Media. Cfr. J. LE GoFf, Una historia del cuerpo en la Edad Media, Buenos Aires, 2005, pp. 43-47, 50-53, 112-114.

59 D. DE ValtanÁs, Exposición sobre el Estado y velo de las monjas, Biblioteca Nacional de España, R-39112. En la campaña de abstinencia sexual llevada a cabo por los religiosos se encontraría el origen cultural de aquella estabilidad demográfica que señalan los especialistas para explicar el crecimiento y la estabilización de las poblaciones de Europa occidental en la Alta Edad Moderna. Cfr. F. PALOMO, «Disciplina Christiana. Apuntes historiográficos entorno a la disciplina ya el disciplinamiento social como categorías de la historia religiosa de la Alta Edad Moderna», en Cuadernos de Historia Moderna, 18, Universidad Complutense, Madrid, 1997.

${ }^{60} \mathrm{El}$ ayuno, rito antiguo inscrito en la tradición bíblica, consistía en privarse, en todo o en parte, de la alimentación, a fin de hacer penitencia y de disponerse a la oración, Dictionnaire de spiritualité, 1974, t. 8, col. 1165-1178.

61 P. DE León, Guía del Cielo, p. 520. Sin el trámite de los ayunos ninguna unión con Dios era posible. «Para esto trabajamos con ayunos y con diligentes vigilias, para que nuestra alma pierda el gusto de las cosas terrenas y ame las celestiales. Porque si en estos ejercicios fuéremos negligentes, luego nuestra alma se aficiona e inclina a los deleites carnales'(c. 17). Y porque el espíritu y la carne ambos son criados por Dios y para Dios, y ambos de compañía entienden en un trato de la gracia de Dios y del reino de los cielos, ayúdanse unos a otros como hermanos y como las dos manos de un hombre. $Y$ de aquí es que, como la carne, pacientemente domada con trabajos y ayunos sirve al espíritu y le en-

Hispania Sacra, Estudios de Edad Moderna, 58

117, enero-junio 2006, 39-67, ISSN: 0018-215-X 
La búsqueda de la anulación pasaría, ante todo, por las privaciones alimenticias, temporales o perpetuas, por las privaciones sexuales y la mortificación del cuerpo $^{62}$. Pero más que la privación temporal de todos los alimentos, exceptuando pan y agua, los observantes dirigen su atención a la privación perpetua de la consumición de carne. Los reformadores se esfuerzan continuamente por obligar a los frailes a abstenerse de la consumición de carne. La legislación aprobada al respecto en el capítulo de 1489 ya recomendaba a los superiores que en la ingestión de carne y el uso de ropa de lino «Praelati non sint faciles ad dispensandum» ${ }^{63}$.

En general los prelados pudieron controlar el cumplimiento de la normativa en el recinto del convento, sin embargo era mucho más difícil hacerlo cuando los frailes se encontraban de viaje, lo cual, entre los dominicos, sucedía con frecuencia, ya fuera por obligaciones ligadas a la cura de alma - predicación, dirección espiritual o confesión-, por negocios de la orden - la asistencia de los prelados a algún capítulo, por ejemplo - o por motivos de estudio. Debido a ello, muy pronto la prohibición de comer carne, así como la de usar ropa de lino, quedaría unida a la de andar a caballo y a la de llevar dinero. «Carnibus commedendis et lineis utendis et pecuniis portandis et in equitatiis Praelati non sint faciles ad dispensandum», reclamaban los reformadores en $1493^{64}$.

No obstante, a diferencia de numerosas reformas que veían en el cuerpo al enemigo que se debía combatir y humillar a través de una operación sacrificial, entre los dominicos reformados de Castilla éste, útil en la labor pastoral, no recibió una calificación tan negativa ${ }^{65}$. Hacia 1515 fray Pablo de León manifestaba, en cierto modo, aquel que sería el pensamiento común de los dominicos re-

gruesa, así el espíritu, bien ordenado con la oración y amorosas afecciones, rige la carne y concierta todos sus sentidos como conviene para su santa mercadería», Juan DE LA CRUZ, O.P., Diálogo..., p. 489.

${ }^{62}$ Sobre los ayunos véase C. BYNuM, Jeûnes et festins sacrés: les femmes et la nourriture dans la spiritualité médiévale, 1994, p. 63.

63 R. HENÁNDEZ, «Actas de la Congregación de la reforma», A.D., I, p. 55.

64 La norma corresponde al capítulo de Toro. R. HENÁNDEZ, «Actas de la Congregación de la reforma», A.D., I, p. 88. Se repite también en el capítulo de Piedrahita de 1495, Idem., p. 118.

65 El castigo del cuerpo era un elemento común a todo el mundo de los religiosos, de hecho entre los dominicos lo testimonia desde el siglo XIII el célebre tratado Los modos de orar de Santo Domingo, que en su tercer capítulo nos muestra al santo que «se levantaba del suelo y con una cadena de hierro se daba la disciplina». Sin embargo, entre los observantes, las prácticas morigerantes extremas se deben asociar a otras familias religiosas, sobre todo al Orden de los Hermanos Menores o a grupos influenciados por éstos, como ocurrió en el caso de los seguidores de la Beata de Piedrahita. Entre los franciscanos la descalsez prolongaría exitosamente estas prácticas a lo largo de la segunda mitad del siglo XVI. Una imagen de todo ello nos la ofrece la misma Teresa de Ávila que al descubrir la asombrosa degradación del cuerpo de Pedro de Alcántara exclamó: «Estaba tan delgado que parecía hecho de raíces de árboles». Vid. J. GÉLIS, «El cuerpo, la Iglesia y lo sagrado», en G. VIGARELLO (dir.), Historia del Cuerpo, I, Madrid, 2005, pp. 54-61. 
formados respecto a este asunto. El fundador del convento de Oviedo considera que los ayunos deben ser practicados de manera racional y proporcionados a cada situación. "Aunque lo manda la religión, no fue intención de la orden obligar contra ley natural y en daño corporal del hombre, ni pudo tener tal intención. Y de allí verán que, como entonces no toman la sustentación que han menester, así para vivir, como para crecer y fortificar el cuerpo, quedan muchas religiosas y religiosos flacos, enfermos y débiles, que después nunca pueden hacer cosas recias de la orden» ${ }^{66}$. Hay que tener en cuenta que la reforma había promovido fuertemente el oficio de la predicación entre los dominicos con el nombramiento de un buen número de predicadores generales, para equilibrar la cantidad de maestros e intelectuales en la Orden, e instando a retomarla a las comunidades que habían abandonado esta actividad central según las Constituciones $^{67}$.

El ejercicio de la predicación era una actividad físicamente penosa porque el fraile se veía obligado a veces a realizar largas caminatas, se exponía a peligros en los caminos, a maltratos y a un agotamiento mental significativo a causa de los problemas que sus fieles le planteaban ${ }^{68}$. Fray Pablo, que había ejercido un incansable apostolado durante treinta años por las montañas de Asturias, exigía una racionalización de la norma general de abstinencia de carne y, a su vez, denunciaba con irritación la existencia de «perlados y padres y madres que tienen hijas devotas, que nunca hacen sino ayunar». En fin, que todos los religiosos no podían estar obligados al ayuno del mismo modo.

Por otro lado, convenía recordar que las obras de caridad eran mucho más

66 P. DE LEÓN, Guía del Cielo, p. 522.

${ }^{67}$ Porque en muchos casos se habían enriquecido y no necesitaban los ingresos obtenidos con este oficio El maestro Vicente Bandelli protestaba en 1504: «Algunos conventos, que tienen posesiones, desprecian el enviar predicadores a los pueblos, diciendo que ellos no padecen necesidad para tener que ejercer ese ministerio. Para remediar tan grande error, según el cual parece a algunos que se ha de predicar no por Cristo sino para conseguir limosnas, mando con todo rigor a los presidentes de los conventos, gravando la conciencia de los mismos, que, teniendo en cuenta las necesidades de los pueblos y su posibilidad, envíen predicadores en la cuaresma y en las festividades, para consolar a las genes. Y declaro que, si por tener posesiones, no quieren predicar con mala conciencia las tienen y contra voluntad de la Orden y contra las intenciones de la sede apostólica». R. HERNÁNDEZ, «Actas de la Congregación de la reforma», A.D., II, pp. 102-103. El capítulo de Valladolid de 1509 estableció el envío de predicadores a las montañas de León y Asturias. R. HERNÁNDEZ, «Actas de los capítulos provinciales», A.D., VII, p. 36. No hay dudas, sin embargo, que el ejemplo de los mismos prelados fue el medio más eficaz para el renacimiento de esta vocación entre los dominicos observantes. La actividad misionera de personajes como fray Pablo de León en esas comarcas, de fray Juan Hurtado en Andalucía y de fray Domingo de Montemayor en Álava, los convirtió en personajes tan legendarios como los misioneros de América. Vid. J. TABOADA, Historia del Convento de Nuestra Señora de Oviedo, editor Lázaro Sastre Varas, Salamanca, 2002, pp. 208-213.

${ }^{68}$ El oficio de fundador y sobre todo de reformador comportaba muchas veces los mismos peligros, la suerte de fray Domingo de Montemayor, asesinado por un grupo de frailes conventuales en 1532, refleja esta situación. J. CUERVo, Historiadores..., III, pp. 582-583.

Hispania Sacra, Estudios de Edad Moderna, 58

117, enero-junio 2006, 39-67, ISSN: 0018-215-X 
importantes que los ayunos: «También no son obligados a ayunar otros, así como si fuesen impedidos en hacer otras obras de más cualidad que fuesen más honra de Dios o del prójimo, no serían obligados a ayunar. Así como si la obediencia mandase a uno predicar o confesar o hacer otro oficio en casa necesario al monasterio, o ir camino, y no pudiese buenamente ayunar, digo que no era obligado ayunar. Y la razón de esto es porque la Iglesia no entiende por el ayuno quitar las obras de caridad o obediencia o justicia o religión, porque éstas son mejores según su especie que no el ayuno. Porque el ayuno lo mandó la Iglesia por nuestros pecados principalmente; y todo lo que hace el ayuno se puede hacer por otras obras de caridad y mejor ${ }^{69}$.

Con todo, ayunos, frío y reposo moderado eran algunos de los medios para hacer penitencia en todos los claustros dominicos ${ }^{70}$. Para resistir el régimen penitencial observante en los conventos dominicos, era necesario tener una sólida constitución física. Por eso la Congregación de la reforma había ordenado que los aspirantes fueran mayores de quince años y de buena complexión ${ }^{71}$. Disposición que fue observada pero que no evitó la fuga o incluso la muerte de numerosos novicios como fruto del rigor de la vida que llevaban ${ }^{72}$. En efecto, la observancia en algunas comunidades hacía estragos. En general las listas de muertos en la Provincia son largas. Sirvan de ejemplo las nóminas de difuntos de dos de las actas más extensas en esta sección, las de 1502 y 1516, redactadas la primera en el período más severo de la reforma y la segunda durante una crisis negativa de reclutamiento. En ellas se registra el deceso de 103 y de 62 frailes respectivamente ${ }^{73}$.

69 P. DE LEÓN, Guía del Cielo, pp. 522-523.

${ }^{70}$ Las disciplinas se debían dar después de las Completas. R. HERNÁNDEZ, «Actas de la Congregación de la reforma», A.D., I, p. 63. Fray Juan de la Cruz, testigo privilegiado de todo ello, cuenta que «los religiosos comúnmente ayunan buena parte del año y mucho más de la mitad (...) por todo el año rompen el sueño a la media noche. Y cuando los seglares que justamente viven están en sus camas durmiendo, los religiosos velan y cantan a voces loores a Dios (...) callo la aspereza y desabrigo de sus vestidos y de sus camas, sus desabridos comeres (...) los oficios trabajosos así al cuerpo como al espíritu, y otros muchos ejercicios de grande aflicción que nadie podrá entender sino quien pasa por ellos (...) lo cual nadie piense que se hace sin trabajo y desvanecimiento de cabeza», J. DE LA CRUZ, Diálogo..., pp. 430-431.

${ }_{71}$ R. HERNÁNDEZ, «Actas de la Congregación de la reforma», A.D., I, p. 89.

72 R. HERNÁNDEZ, «Actas de la Congregación de la reforma», A.D., I. p. 117. Únicamente los privilegios provenientes de un origen noble pudieron salvar la vocación religiosa de algún novicio más frágil: «El 25 de noviembre de 1496 tomó el hábito fray García de Loaysa, hermano, como dijimos de fray Domingo de Mendoza, naturales de Talavera y de nobilísima sangre. No hizo fray García profesión en este Convento por causa de enfermedad, que casi obligó a los Padres a quitarle del todo el hábito por parecerles que no podría sufrir los rigores de la Orden. Su hermano compuso que no se le quitase, sino que le enviasen en otro Convento en donde con otros aires y menor peso en las observancias regulares pudiese convalecer u proseguir en la Orden», J. CUERVo, Historiadores..., III, p. 505.

73 R. HERNÁNDEZ, «Actas de la Congregación de la reforma», A.D., II, pp. 84-87; «Actas del capítulo provincial de 1516», A.D., XIV (1993), pp. 33-35. 
Paradójicamente, la experiencia permanente de la finitud de la vida humana, producto de la misma austeridad y dureza de la vida observante — que el fraile podía constatar frecuentemente en su propia comunidad - incentivaba la imitación de la Passio Christi y con ella las mortificaciones. La incesante meditación en la muerte estimulaba su búsqueda ${ }^{74}$.

\section{ENCERRAR Y SEPARAR AL RELIGIOSO}

La cuaresma perpetua, los ayunos y la castidad fueron algunos de los medios que permitían a los frailes la anulación de los deseos y de las sensaciones corporales. Para reprimirlas se impuso también la clausura y un mayor control en las entradas y salidas del convento.

Si la clausura del convento contribuyó al recogimiento devocional promovido por la observancia, ésta fue considerada sobre todo un medio eficaz «para la seguridad y cautela de los flacos. Porque más vehementes pasiones se crían con la presencia y trato de las cosas deleitables que con su ausencia y apartamiento de ellas». Los reformadores creían que el religioso era un ser de naturaleza frágil, ¿acaso no había afirmado San Pablo que la «locura» de Dios era precisamente haber elegido entre todos los hombres a los necios y a los débiles para mejor manifestar su gloria ? $^{75}$ Llamados por Dios a abrazar una forma de vida que superaba sus capacidades, los frailes debían, por lo tanto, ser protegidos de las tentaciones, "porque para remedio de la humana flaqueza pareció provechosísima observancia morar los frailes en los monasterios y no discurrir por diversas regiones y tardar mucho fuera de sus casas, porque no les acaezca lo que a los peces fuera del agua, que luego mueren» ${ }^{76}$. Esta última amonestación explica, además, la dureza de las penitencias establecidas contra los frailes giróvagos o fugitivos, tan reprobados por los capítulos de la reforma.

El vestido también debía distinguir, proteger y separar al religioso del resto de los mortales. En efecto, en 1509 los superiores provinciales exigían a los frailes «extra conventum debemus caput coopertum deferre propter Ordinis honestatem» ${ }^{77}$. El hábito religioso debía contribuir además a ubicar al fraile den-

74 Fray Domingo de Montemayor, profeso de San Esteban de Salamanca, embarcado en la reforma de los conventos valencianos fue acuchillado en la cabeza y en el hombro por unos frailes conventuales, "alegrábase en mucho de ver que en su muerte imitaba a Cristo, y eran grandes las alegrías de su alma viendo ya tan cerca la corona del martirio, y así llegando a quererle consolar un religioso, y diciéndole que sería Dios servido de sacarle del peligro en que se hallaba de sus vida, con el gesto dio bastantes señas de que no le alegraba aquella plática, que le privaba de aquella gloria de imitador de Cristo», J. Cuervo, Historiadores..., III, p. 583.

75 Cor $1,25-29$.

76 J. DE LA CRUZ, Diálogo..., p. 459.

77 R. HERnÁnDEZ, «Actas de los capítulos provinciales de la provincia de España del siglo XVI (II)», A.D., VII (1986), p. 34. 
tro del control social. El mismo San Bernardo, tan leído por los observantes, había advertido cuánto era inconveniente "que de una pieza de paño corte el caballero su capa y el monje su cogulla» ${ }^{78}$. Por otra parte, la sociedad general tomaba el relevo de la autoridad conventual para asegurar la vigilancia de las normas religiosas fuera del claustro ${ }^{79}$. Revestido de un hábito distintivo y respetable, el religioso difícilmente podía ocultar su falta a la mirada de la sociedad y por lo tanto quebrantar sus votos sin escándalo social.

Asimismo, este singular vestido estaba previsto para guardar al fraile en el cumplimiento de todas las virtudes ya que servía para desalentar a todos aquellos que quisieran ser con ellos irrespetuosos o pretendieran otro trato que no fuera aceptable a su condición, "porque la santidad y dignidad de su estado no puede ser manifiesta a los hombres sino por señales sensibles, entre las cuales es muy fácil y eficaz la diferencia de vestido» ${ }^{80}$. Por eso, el vestido no sólo separaba al dominico de los demás, sino que le debía recordar las virtudes inherentes a la profesión religiosa: «No es solamente aviso el vestido de los religiosos a los extraños, mas principalmente a ellos mismos amonesta y enseña cual es o debe ser el hábito interior, conviene saber, despreciador de la pompa mundana y amador de la pobreza y de otras muchas virtudes que el exterior hábito representa». La simbología aneja al hábito continuaba en una serie de actitudes

78 B. DE Claraval, Apología ad Guillelmum abbatem, En la sociedad medieval cada individuo adoptaba el vestido que le correspondía de acuerdo con su pertenencia a un grupo definido por el sexo, la posición socio-económica, el grupo étnico-religioso, la edad, la profesión o la enfermedad. Se trataba de una preocupación sobre todo del clero y de todos aquellos que necesitaban hacerse obedecer, en medio de una sociedad que consideraban insolente. Tal como lo demuestra Fray Hernando DE TALAVERA en «El tratado sobre el vestir, calzar y comer del arzobispo Hernando de Talavera», Revista Espacio, Tiempo, Forma, Serie III, Historia Medieval, 14, 2001, pp. 11-92. Michel Pastoureau afirma que «dans le vêtement médiéval tout est signifiant. Chacun doit porter le vêtement de son état et de son rang. Se vêtir plus richement ou plus pauvrement qu'il n'est d'usage dans la classe ou le milieux auquel on appartient, est un péché d'orgueil ou une marque de déchéance. Le vêtement a pour rôle principal d'indiquer la place d'un individu au sein d'un groupe et la place de ce groupe au sein de la société. C'est un système de signes rigoureux et contraignant», Couleurs, images, symboles. Études d'histoire et d'anthropologie, 1989, p. 32. Cfr. J. M. MAERTEns, Dans la peu des autres, Ritologiques, 4, 1978. En la sociedad medieval cada individuo adoptaba el vestido que le correspondía de acuerdo con su pertenencia a un grupo definido por el sexo, la posición socio-económica, el grupo étnico-religioso, la edad, la profesión o la enfermedad

79 «Y así donde quiera que vaya o esté el religioso, trae consigo delante de sí y de todos el testimonio de su obligación, con que no solamente su conciencia le acusa, más sabe que todos cuantos le ven le pondrán en juicio si no vive como viste». Juan DE LA CRUZ, Diálogo..., p. 463.

80 J. DE LA CRUZ, Diálogo..., p. 462. Si el hábito era el signo de la presencia de un consagrado a Dios, entonces esa misma señal no podía dejar de estar revestida de sacralidad, al menos en el plano de la percepción social. El carácter sacro del hábito y por lo tanto su poder de liberar de los pecados será confirmado por visones de los santos fundadores o de la Virgen, que indica el hábito de la Orden, tal como sucedió a Santo Domingo, y asocia a quienes lo llevan privilegios de buena muerte o de una rápida liberación del purgatorio. Cfr. S. ABBRUZZESE, «Sociología dell'abito religioso», en G. RocCA (dir.), La Sostanza dell'Effimero, Roma, 2000, pp. 119-123. 
interiores exigidas al fraile: «Porque la materia de que es hecho, que es paño vil y grosero, amonesta al amor de la pobreza y humildad (...) Asimismo amonesta el hábito religioso que procure agradar a solos ojos de Dios, que ve lo escondido, no a los ojos de los hombres (...) En su sencillez, que no tienen aforros ni guarniciones, muestra la simplicidad de intención que el buen religioso tiene con Dios y con los prójimos (...) significan también por su aspereza y desabrigo el propósito de penitencia que el religioso tiene (...) por ser cerrado y cumplido hasta los pies, la honestidad y mesura que en las almas tienen» ${ }^{81}$.

Entre los observantes el hábito, aparte de ser el reflejo de un discurso exterior del cuerpo que puede ser asumido, rechazado o manipulado por el individuo, era un elemento constitutivo del ser, el que daba al fraile una identidad y lo presentaba ante los otros. El pensamiento cristiano afirmará, recogiendo esta idea, que hay una estrecha relación entre la indumentaria y el estado del alma, algo que ya había indicado el autor del Eclesiastés: «la vestidura del cuerpo exterior denuncia y muestra lo que es el hombre» (Ec. 19, 27) ${ }^{82}$. En la tradición cenobítica, la forma en que un monje vestía significaba aquello que era, constituía su «verdadero ser monástico» ${ }^{83}$.

Toda la legislación de los dominicos castellanos a partir de 1489 se empeña en recordar a los frailes las prescripciones oficiales sobre el hábito, detallando medidas, colores y peculiaridades de los paños con que se deben confeccio$\operatorname{nar}^{84}$. Ante todo el fraile debía poseer solamente los vestidos necesarios y éstos debían ser sin artificios: «tunica superior descendat usque ad cavillam pedum vel saltem quod no tangat terram et quod rotunditas inferior sit viginti quatuor palmorum ad plus. Cappa vero sit brevior tunica per semisem, cuius rotunditas inferior sit ad mensuram tunicae, preterquam si sit de estameña, quia tunc poterit attingere viginti octo palmos et non ultra. Scapularia autem breviora sint cappis» ${ }^{85}$. Si pasaban frío «vestes inferiores duplicantur, non tamen superiores, et similiter tunicae inferiores quae vulgo nostro dicuntr sacosaios non sint longiones quam ultra quatuor digitos infra genua, et vilibus pannis induantur fratres nostri et potius vilitas in cappis observentur...» ${ }^{86}$. Estaban estrictamente prohibidos el lino y cualquier tipo de tejido suave en la ropa interior ${ }^{87}$.

81 J. DE LA CRUZ, Diálogo..., pp. 462-463.

82 La idea de identidad creada a través del vestido aparecerá en toda la literatura didáctica medieval, Vid. O. BLANC, «Vêtement féminin, vêtement masculin à la fin du Moyen âge. Le point de vue des moralistes», Le vêtement. Histoire, archéologie et symbolique vêtimentaires au Moyen Àge, 1989, pp. 243-253.

${ }^{83}$ L. SAGGI, «Abito religioso», Dizionario degli Istituti di Perfezione, I, p. 50.

84 Sobre el hábito de los dominicos véase, V. FerRUA, «L'habit des Frères Prêcheurs. Jalons pour une histoire», en Mémoire Dominicaine, 12 (1980/1), pp. 143-183.

85 R. HERNÁNDEZ, «Actas de la Congregación de la reforma», A.D., I, p. 62.

86 R. HERNÁNDEZ, «Actas de la Congregación de la reforma», A.D., II, p. 61.

87 R. HERNÁNDEZ, «Actas de la Congregación de la reforma», A.D., II, p. 96.

Hispania Sacra, Estudios de Edad Moderna, 58

117, enero-junio 2006, 39-67, ISSN: 0018-215-X 
A su vez las actas de los capítulos de la provincia de 1508 y de 1509, ayudaron a definir las singularidades del hábito de los frailes al corregir las exageraciones de los seguidores de la Beata de Piedrahita, porque «unius professionis voto vivimus uniformes in omni religiositate inveniri debemus et uniformitatem cordium in uniformitate vestium repraesentemus» ${ }^{88}$. El capítulo de 1509 exigía específicamente para la capa cuatro dedos por encima del suelo; el escapulario, que fuera más corto que la capa y una cuarta parte más corto que la túnica; el escapulario y la capa debían estar unidos a sus respectivas capuchas. Entre los frailes clérigos la túnica debía ser blanca, así como el escapulario, mientras que la capa negra.

Por otro lado, el hábito sirvió para distinguir netamente a los frailes laicos de los seculares, dentro de una misma comunidad. «Fratibus laicis qui mutaverunt vel de cetero mutabunt habitum nigrum in album nullo modo recipientes, de gradibus non suscipiendis nisi secundum privilegia Congregationis» ${ }^{89}$, ordenaba a los priores conventuales el capítulo de 1500. Al penalizar duramente a aquellos que se atrevían a travestir, obstaculizaron e hicieron imposible el cambio de hábito y la promoción de los legos al sacerdocio. El movimiento reformista en este campo, integraba en sus ordenaciones una serie de pautas que le permitían jerarquizar a los miembros de la comunidad religiosa, como la sociedad externa análogamente jerarquizaba a los grupos sociales entre $\mathrm{si}^{90}$.

\section{¿EJEMPLARES O MEDIADORES?}

Comidas y vestido mortificantes respondían a una representación de la sociedad y de si mismos que los dominicos elaboraron a lo largo de la reforma. En la ciudad los frailes consideraban que debían, antes que nada, exhibir su perfección. Anhelaban, a través de su ejemplo, poder contribuir eficazmente a la reforma de todos. Todos debían reconocer que el religioso había sido separado

${ }^{88}$ R. HERNÁNDEZ, «Actas de los capítulos provinciales de la provincia de España del siglo XVI (II)», A.D., VII (1986), p. 21. Sobre todo recuerdan a los frailes las disposiciones constitucionales del capítulo de Narbona de 1354 sobre los hábitos M.O.F.P.H., IV, pp. 358, 360.

89 R. HERnÁNDEZ, «Actas de la Congregación de la reforma», A.D., II, p. 59.

90 «A partire dal momento in cui l'indicazione della funzione prende il sopravvento sul messaggio edificante, l'abito religioso non può non «specializzarsi». In una società rigidamente distinta in mestieri e corporazioni, tutte ben identificabili attraverso i segni dell'abbigliamento, i religiosi devono ben presto segnalare la loro condizione ad extra, mentre ad intra è sempre più indispensabile distinguere $\mathrm{i}$ diversi Ordini tra loro e i diversi gradi d'appartenenza all'interno dello stesso Ordine», S. ABBrUZZESE, «Sociología dell'abito religioso», en G. Rocca (dir.), La Sostanza dell'Effimero, Roma, 2000, p. 120. De hecho, en virtud de las prohibiciones al estudio y a la posesión de libros por parte de los frailes laicos, el patrón diferenciador en los conventos dominicos estaría dado sobre todo por los estudios. Había, en consecuencia, frailes letrados y aquellos que no lo eran, con roles y estatus bien definidos ad intra conventum. 
del mundo «como aquellas doce piedras que Josué sacó de medio del río Jordán y las asentó en tierra firme para que fuesen amonestación y recuerdo de Dios a todos los que las viesen» ${ }^{91}$. De hecho, el conjunto de los clérigos debía conformar un espejo para los demás ya que existía una jerarquía de vías de perfección según se fuera monje, clérigo o se estuviese casado. En esa jerarquía la vida regular era superior por ser la más conforme a la vida de Cristo ${ }^{92}$.

Sin embargo, esta concepción jerárquica de la sociedad y de la Iglesia no era una creación caprichosa de los religiosos, sino un producto de la sociedad castellana de cara a la salvación eterna ${ }^{93}$. Evidentemente, el final del siglo XV estuvo marcado en Castilla por una sed insaciable de intercesión. La reforma de los monasterios y conventos suscitó un entusiasmo inaudito de los laicos por la mediación de los frailes. En esta comunión de santos los religiosos no dejaron de responder a las esperanzas de los laicos ${ }^{94}$.

Los reformadores dominicos, como en general todos los observantes, creían en la utilidad de la mediación de los frailes. Reformar fue, por lo tanto, una acción dirigida a mejorar la calidad de esa intercesión. El fraile que no observaba los preceptos de la vida religiosa cargaba su conciencia ya que contravenía la caridad de Cristo, de aquí el desprecio hacia la conventualidad. Por eso los reformadores y los directores espirituales señalaban con fuerza que «no hay demonio en el infierno tan malo como el mal religioso» ${ }^{95}$.

Imitando a Cristo, en su rol de víctima redentora, los buenos religiosos eran los intercesores más eficaces en el momento de la muerte. De allí que, por la violencia que los observantes ejercían contra sí mismos, el conjunto del monacato fue percibido, tanto por la sociedad como por las autoridades reformadoras, como una expiación indispensable a favor de la humanidad. Al igual que

91 J. DE LA CRUZ, Diálogo..., p. 462.

92 En concordancia con ese principio, el concilio de Trento dispondrá: «Si alguno dijere que el estado conyugal debe anteponerse al estado de virginidad o de celibato, y que no es mejor y más perfecto permanecer en virginidad o celibato que unirse en matrimonio [cf. Mt. 19, $11 \mathrm{~s} ; 1$ Cor. 7, $25 \mathrm{~s} 38$ 40], sea anatema». Denzinger, H. HünERMAnN, P. El Magisterio de la Iglesia. Enchiridion Symbolorum, definitionum et declarationum de rebus fidei et morum, 2000, 2. a edición, p.nn. 1810.

93 Cfr. A. RucquoI, «Mancilla y limpieza: la obsesión por el pecado en Castilla a fines del siglo $\mathrm{XV}$ », en Os «últimos fins» na Cultura Ibérica (XV-XVIII), Rev. Fac. Letras, Lenguas e Literaturas, Anexo VIII, Porto, 1997, pp. 113-135.

94 Una práctica que se consolidaría a lo largo del siglo XVI, como da prueba sobre todo la elección de sepultura en las iglesias parroquiales de los conventos observantes. Uno de los casos más llamativos es el del convento de San Esteban de Salamanca. Si bien este cenobio, residencia de estudiantes y de maestros de la Universidad, recibió heredades y bienes como legado testamentario a lo largo del siglo $\mathrm{XV}$, con cargas de misas y oraciones, desde su paso a la reforma, en 1486, suscitó un atractivo especial entre la alta nobleza castellana y grandes propietarios, así como entre los mismos monarcas castellanos. Desde entonces, las grandes donaciones, cesiones y privilegios eclipsaron a los medianos y pequeños que caracterizaron al período precedente. Vid. AHN, Clero, leg. 1923, 5919, 5920 y 5937.

95 D. DE ValtanÁs, Exposición sobre el estado y velo de las monjas, fol. XIII.

Hispania Sacra, Estudios de Edad Moderna, 58

117, enero-junio 2006, 39-67, ISSN: 0018-215-X 
Cristo el fraile «ha de poner la vida por los hermanos y prójimos cuando fuese menester, porque no se pierda lo que a Cristo tanto costó» ${ }^{96}$. Intercesor y chivo expiatorio, chivo expiatorio y en consecuencia intercesor, el religioso se transformaba en víctima y mediador ${ }^{97}$.

Con tantos sacrificios a sus espaldas, los frailes se convirtieron en la mejor de las mutuales de oración. En efecto, si bien antes de la reforma los testamentos que beneficiaban a los conventos dominicos, acordaban la celebración de misas votivas por la salvación del alma del donante, con su incorporación a la observancia se advierte que esos cenobios pasaron a convertirse en un centro de atención de la aristocracia como no lo habían experimentado hasta entonces, abultándose al mismo tiempo ese tipo de comisión.

La cura monialium se inscribía además en esa economía de la salvación, que es la comunión de los santos en el cuerpo místico de Cristo, caracterizada por la reversibilidad de los méritos, el don y el contra don. En esta concepción la oración de los frailes tenía un valor eminente, «todo se alcanza con oración y sin ella ninguna cosa. Si perdón de los pecados, si letras, si algo bueno, todo viene por la oración». La necesidad de su práctica estaba bien definida: «orar no es otra cosa sino demandar a Dios lo que a él es honesto dar y a nos pedir (...) las oraciones nuestras son ejecuciones y causas instrumentales de la voluntad de Dios». Los frailes estaban obligados, pues, a orar no solamente por ellos mismos «más aún por nuestros prójimos en cuando son conjuntos a nos, agora por caridad y amor natural, agora por gratuita ${ }^{98}$.

96 P. DE LEÓN, Guía del Cielo, pp. 191-192.

97 «En la Escritura siete sacrificios podemos notar. El primero que es del corazón contrito (...) Éste es el sacrificio de los pecadores y el primero que pueden ofrecer antes de todos (...) El segundo sacrificio es de corazón ya encendido en amor, y este sacrificio es ya del justo (...) este sacrifico ofreció San Pedro después que hubo contrición de su pecado (...) El tercer sacrificio es del cuerpo mortificado. Porque el que mortifica su cuerpo con ayunos, abstinencias, disciplinas, éste ofrece a Dios sacrificio de penitencia. Y tal fue el de la Magdalena, que después de la Ascensión de Nuestro Señor tantos años estuve en aquel yermo sola sin ayuda humana. Tales sacrificios hicieron muchos santos, que todo su cuerpo no era sino cribo agujereado con dolores, llagas y azotes y otras mil maneras de penitencia. El cuartos sacrifico es que no sólo él aflige su cuerpo o su voluntad, más aún lo ofrece a otros enemigos que no tengan piedad del cuerpo, sino que a su voluntad de ellos lo desuellen y atormenten; como fueron los mártires, que no les bastó las abstinencias propias, más aún andaban a buscar sayones y justicias que por amor de Dios [en] ellos hiciesen sacrificio. Vergüenza tengan los que toda su vida no es sino criar este cuerpo en delicadezas, y así como en vestir, que toda su bienaventuranza es esta, y en holgar. El quinto sacrifico es de loores y alabanzas a Dios (...) Harto sacrificio es todos los días maitines, prima, tercia, sexta, nona y todo lo demás; que si con devoción es dicho, a las veces queda el hombre sin espíritu, medio muerto. El sexto sacrifico es de las cosas temporales que a los pobres damos. Harto sacrifico es el de la misericordia, con al cual quitamos de nos el subsidio temporal y lo damos a los pobres de Jesucristo. De manera que ni ánima, ni cuerpo, ni bienes temporales dejan los buenos sin hacer de ellos sacrifico (...) Estos sacrificios ofrezcamos cada día a Dios, si pudiéremos, y valdrá tanto como ir a Jerusalén», P. DE LEÓN, Guía del Cielo, pp. 326-328.

98 «Es de saber que el amor con que se aman los miembros unos a otros nos muestra cómo debe- 
La asistencia de los frailes, sin embargo, no beneficiaba solamente a los muertos o a los que se encontraban al borde de la muerte, los vivos se veían favorecidos también por ella. La liturgia preveía estas intercesiones cotidianas por los vivos. Obviamente los primeros beneficiados por este servicio fueron los monarcas y a continuación una abultada nómina de fieles devotos ${ }^{99}$. La mayoría de los dominicos eran sacerdotes, se comprende entonces que las misas votivas fueran distribuidas entre los frailes de tal modo que se pudieran cumplir las obligaciones contraídas por los beneficiarios de esta práctica. Aquellos que solicitaban la intercesión de los frailes no dejarían escapar esta particularidad.

A partir de estos presupuestos, los dominicos contribuyeron a revalorizar una concepción inmolatoria del sacerdocio. El sacerdote era el hombre que reiteraba el sacrifico salvador, «ofrecer el cuerpo de Nuestro Señor Jesucristo, que después que todo cuanto somos le hemos ofrecido, demandamos a Nuestro Señor su cuerpo y ánima y divinidad para que nos lo pague y nos hincha de sus virtudes y gracia». El poder de celebrar la eucaristía distinguía al sacerdote del laico. Separados de los laicos por su estado de vida, los frailes dominicos recordaron, de este modo, que junto a su singular perfección religiosa revestían también la superioridad funcional que confería el sacerdocio y el poder de consagrar. En ellos la jerarquía de la santidad coincidía con la de las órdenes ${ }^{100}$.

\section{CONCLUSIÓN}

El movimiento observante entre los dominicos desarrolló su virtualidad a partir de la última década del siglo XV. Bajo el impulso del retorno a los orígenes y en el contexto de una sociedad al mismo tiempo en expansión y temerosa del pecado, las comunidades dominicas castellanas desarrollaron un proceso de autoconciencia y categorización que dio como resultado la configuración de un

\footnotetext{
mos amar a los prójimos (...) porque los ojos para todos los miembros ven, y los pies para todos lo miembros andan, y así de los otros miembros». P. DE LEÓN, Guía del Cielo, pp. 190, 194, 313, 314, 315 y 320 .

99 «sobre todo porque los serenísimos Reyes Católicos favorecían a medida de el grande amor que sus Majestades y sus hijos profesaban a la Orden, su reforma en sus dominios mediante su poder y autoridad, mandan que por sus reales personas y las de sus hijos celebre dos missas cada sacerdote de la Congregación, con sus assignado a los demás frailes clérigos y de fuera de coro», R. HERNÁNDEZ, «Actas de la Congregación de la reforma», A.D., I, p. 139.

100 Es cierto que esta concepción inmolatoria no excluía para nada la virtud necesaria del sacerdote. Pero, si bien era obligatorio mostrarse digno del sacrificio que se celebraba, el sacerdocio no dependía de una virtud, que no exigía en razón del poder consagratorio del sacerdote. Si en algún caso el sacerdote era indigno, su poder sacerdotal quedaba inalterado, porque es Dios quien actúa por medio del sacerdote cuando este consagra las especies. La reforma, sin embargo, se había encargado de prevenir que justamente esta última eventualidad no se verificara, puesto que la vida piadosa del fraile debía, además, suscitar la conversión de la sociedad entera.
}

Hispania Sacra, Estudios de Edad Moderna, 58

117, enero-junio 2006, 39-67, ISSN: 0018-215-X 
modelo de vida regular en el que la frecuentación de los sacramentos de la Penitencia y de la Eucaristía, así como la prácticas corporales morigerantes adquirieron la categoría de rasgos distintivos de los frailes reformados.

A la luz de la Patrística, de la tradición monástica medieval y del pensamiento de teólogos y santos de la Orden, la práctica sacramental trajo consigo la definición de los mismos sacramentos y de su acción en el creyente. Los frailes se convirtieron, de este modo, en una elite privilegiada dentro de una Iglesia entendida según unos grados de perfección bien definidos.

En ese mundo decadente, hacerse religioso se convirtió en el mejor modo de alcanzar la salvación. Los dominicos reformados se incluyeron en la comunión de los santos y en una vida religiosa saturada de intercesores. Asiduos practicantes de la comunión y de la confesión sacramental, sostenidos por los votos y por la regla, los frailes habían recibido más que los demás cristianos, semejante a cuánto habían sacrificado en esta vida. La vida religiosa se convirtió en una alternativa a la vida profana, en cierto sentido la realización de una utopía.

La reforma monástica se encargó de revitalizar, en el alba del Renacimiento, en la sociedad castellana, la preeminencia espiritual de los monjes del pasado. Si bien con las atenuaciones correspondientes, la observancia hizo que la santidad fuera confundida fácilmente con la vida penitencial — sinónimo del monaquismo - y, en consecuencia, un fraile o una comunidad fueron más santos y, por consiguiente, más atractivos y poderosos, cuanto más penitentes habían sido. 